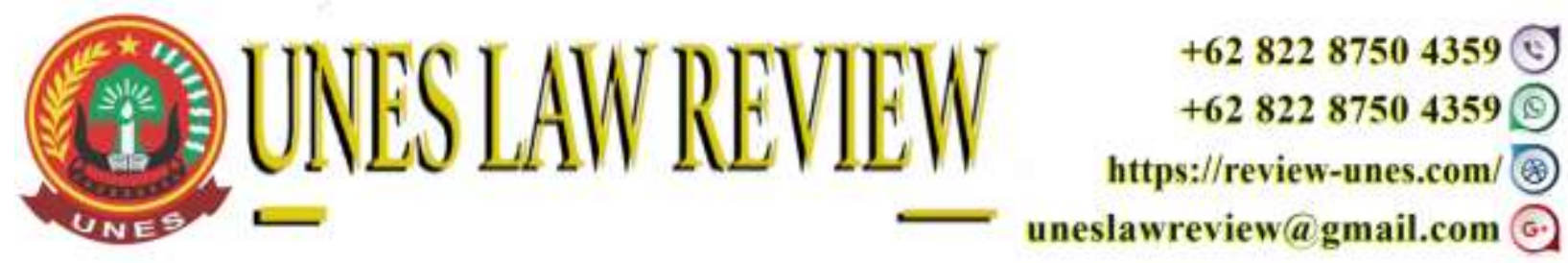

DOI: https://doi.org/10.31933/unesrev.v3i1

Diterima: 01/10/2020, Diperbaiki: 20/10/2020, Diterbitkan: 21/11/2020

\title{
ANALISIS KRIMINOLOGI TINGGINYA ANGKA KECELAKAAN LALULINTAS DI WILAYAH HUKUM POLRES PESISIR SELATAN
}

\section{Muhammad Rafki}

Program Magister Ilmu Hukum, Universitas Ekasakti, Padang, Indonesia

Email: muhammadrafki@ymail.com

Corresponding Author: Rafki

\section{ABSTRACT}

On the South Coast there is an increasing number of accidents every year. The criminological factor of the high number of traffic accidents in the Legal Area of the Pesisir Selatan Police is a factor of road conditions because Pesisir Selatan Regency has a geographical condition as a hilly plateau and is located along the southern coast of Sumatra. Another factor for community domesticated livestock is cows that are allowed to roam around without a leash. Efforts to Overcome Traffic Accidents in the Legal Area of the Pesisir Selatan District Police are carried out with several aspects, namely the engineering aspects of road maintenance and infrastructure, installation of markers, installation of warning lights (flip flop lights), installation of signs, and speed restrictions. The education aspect is carried out by improving motorist behavior, through appeals and training. Externally the obstacle faced is the lack of cooperation between the traffic police and other agencies related to traffic such as the transportation department and the nagari administration. The low level of legal awareness of road users in carrying out their work, namely driving their vehicles in accordance with good and correct driving operational standards, is often not applied by violating traffic regulations.

Kata Kunci: Kecelakaan, Lalulintas, Kriminologi

\section{PENDAHULUAN}

Menurut Pasal 1 angka 24 UU No. 22 Tahun 2009 tentang Lalu Lintas dan Angkutan Jalan ("UU LLAJ"), kecelakaan lalu lintas adalah suatu peristiwa di Jalan yang tidak diduga dan tidak disengaja melibatkan Kendaraan dengan atau tanpa Pengguna Jalan lain yang mengakibatkan korban manusia dan/atau kerugian harta benda. Kecelakaan lalu lintas yang mengakibatkan korban meninggal dunia termasuk kecelakaan lalu lintas berat (Pasal 229 ayat (4) UU LLAJ).

Untuk menekan angka kecelakaan lalu lintas yang dirasakan sangat tinggi, upaya ke depan diarahkan pada penanggulangan secara komprehensif yang mencakup upaya pembinaan, pencegahan, pengaturan, dan penegakan hukum. Upaya pembinaan tersebut dilakukan melalui 
peningkatan intensitas pendidikan berlalu lintas dan penyuluhan hukum serta pembinaan sumber daya manusia.

Pada Paragraf 9 UULLAJ tentang Tata Cara Berlalu Lintas, bagi pengemudi kendaraan Bermotor salah satunya Pasal 126 UULLAJ yang menjelaskan kewajiban Pengemudi Kendaraan Bermotor Umum dan masih banyak pasal-pasal lainnya yang terkait dengan berbagai kewajibankewajiban yang harus ditaati oleh pengemudi kendaraan bermotor. Akan tetapi kenyataan yang terjadi dilapangan kususnya dalam wilayah hukum Kabupaten Pesisir Selatan.

Pengguna jalan raya mempunyai tanggung jawab untuk dapat melaksanakan kewajibannya yaitu mematuhi peraturan lalulintas. Terwujudnya kenyamanan bagi pengguna kendaraan. Sehingga tujuan pengangkutan dapat terlaksana dengan lancar dan sesuai dengan nilai guna masyarakat. Penguna jalan raya yang tidak mematuhi pertauran lalulintas sering berakibat timbulnya kecelakaan lalulintas. Di Pesisir Selatan sering terjadi kecelakaan akibat kelalaian dari pengguna jalan raya.

Mengingat pentingnya ketertiban lalu lintas demi kelancaran dan keselamatan para pengguna jalan pada umumnya, maka perlu diupayakan tumbuhnya semangat untuk menaati aturan, semangat untuk menjaga ketertiban, dan menghormati hak orang lain dalam berlalu lintas. Selain itu, dengan langkah-langkah penegakan hukum oleh Polri diharapkan akan tercipta keadaan tertib hukum dibidang lalu lintas dan angkutan jalan raya sehingga berbagai pelanggaran lalu lintas dapat ditekan jumlahnya seminimal mungkin. Banyaknya kasus tindak pidana pelanggaran lalu lintas yang terjadi di Kabupaten Pesisir Selatan yang dilakukan oleh masyarakat. Oleh karena itu penting pula kiranya dilakukan penelitian tentang penyebab terjadinya kecelakaan lalulintas agar dapat diformulasikan upaya upaya untuk menanggulangi kecelakaan lalulintas tersebut.

Berdasarkan latar belakang pemikiran di atas, maka permasalahan Faktor penyebab tingginya angka kecelakaan lalulintas di Wilayah Hukum Polres Pesisir Selatan dan Upaya serta kendala yang dihadapi penanggulangan kecelakaan lalulintas di Wilayah Hukum Polres Pesisir Selatan.

\section{METODE PENELITIAN}

Spesifikasi penelitian adalah deskriptif analitis, dengan metode pendekatan yuridis normatif didukung oleh yuridis empiris. Jenis data yang digunakan adalah data sekunder dan data primer. Data yang diperoleh kemudian dianalisa secara kualitatif .

\section{HASIL DAN PEMBAHASAN}

\section{Faktor Penyebab Tingginya Angka Kecelakaan Lalulintas Di Wilayah Hukum Polres Pesisir Selatan}

Kecelakaan lalu lintas merupakan kejadian rutin di jalanjalan di seluruh dunia. Ribuan orang kehilangan nyawa mereka di jalan setiap hari. Banyak jutaan lainnya mengalami kecacatan dalam kehidupannya. Anak-anak dan dewasa muda merupakan usia yang rentan dengan kejadian kecelakaan. Setiap jam setiap hari, empat puluh remaja meninggal akibat kecelakaan lalu lintas. Artinya setiap hari ada seribu lainnya keluarga harus mengalami kehilangan orang yang dicintai. Kecelakaan yang melibatkan sepeda motor dan kendaraan lainnya terjadi sekitar 50\%. Mengingat tingkat kematian pengendara sepeda motor meningkat dari tahun 2010 sampai 2018 di Kabupaten Pesisir Selatan. 
Beberapa negara mengidentifikasi ada tiga penyebab utama kecelakaan lalu lintas yaitu faktor manusia, faktor kendaraan dan faktor jalan atau lingkungan. Ketiga faktor tersebut ada di Indonesia (Panadeng, Robert, Hernowo Wibowo, dan Bien Pasaribu, 1993:68). Faktor utama penyebab kecelakaan lalu lintas adalah faktor manusia. Manusia banyak melakukan pelanggaran terhadap aturan lalu lintas. Pelanggaran rambu lalu lintas merupakan salah satu penyebab terjadinya kecelakaan lalu lintas. Pelanggaran tersebut diakibatkan karena kesengajaan maupun kurangnya kontrol diri pada pengemudi terhadap peraturan yang berlaku. Dari kuisioner yang disebarkan terlihat 58,8\% dari pengguna jalan yang berkendara mengalami pelanggaran rambu lalulintas. Pengendara motor yang melakukan pelanggaran terjadi karena rendahnya kontrol diri dari pengemudi, seperti mengendara dalam keadaan sakit atau tekanan psikologi.

Demikian juga halnya pada faktor kepribadian juga dapat mempengaruhi pelanggaran sehingga dapat menyebabkan kecelakaan lalu lintas. Menuurt teori Psikologi kriminal dalam ilmu kriminologi, tipe kepribadian terbagi menjadi dua bagian, yaitu kepribadian introvert dan kepribadian extrovert. Tipe kepribadian introvert cenderung menutup diri dari lingkungan sekitarnya, serta keputusan yang diambil hanya didasarkan oleh perasaan, pemikiran, dan pengalaman dari individu. Tipe kepribadian ini akan menimbulkan sifat ego sentries yaitu sifat yang lebih mementingkan diri sendiri dan kurang memperhatikan dan atau kurang menghargai orang lain, sehingga dalam berlalu lintas mudah menimbulkan kecelakaan, karena semua yang ada di sekitarnya dianggap hanya untuk kebutuhan dan kepentingannya sendiri. Misalnya helm yang tidak ditalikan sehingga saat kendaraan dilarikan dalam kecepatan tinggi, helm tersebut dapat terbang tertiup angin, hal ini sangat membahayakan pengendara yang ada di belakangnya.

Sementara untuk kepribadian extrovert, seseorang cenderung lebih aggressive, sehingga keputusan yang diambil berdasar dari pengalaman teman sekitarnya. Sifat agresif ini mempunyai ciri-cirinya kurang sabar, penuh rasa persaingan, mudah menyerang dan menyalahkan orang lain, sehingga kendaraan yang dikendarai dapat digunakan sebagai alat untuk melampiaskan nafsu agresifnya untuk menyerang orang lain, sehingga mudah terjadi kecelakaan. Insiden kecelakaan lalu lintas pengendara kendaraan bermotor terutama pada remaja yaitu 11\%, dan lebih dari 50\% korban kecelakaan lalu lintas mengalami lebih emosional dan adanya gangguan kognitif dan sosial.

Laki-laki dari usia muda, lebih cenderung mengalami kecelakaan lalu lintas di jalan daripada perempuan. Hal ini terlihat dari data pelaku kecelakaan berdasarkan jenis kelamin di Wilayah Hukum Satlantas Polres Pesisir Selatan yaitu 77\% dibandingkan pelaku perempuan. Hal ini disebabkan Laki-laki lebih cenderung tidak menaati peraturan yang ada, sedangkan perempuan lebih mementingkan peraturan yang ada. Menurut data Satlantas Polres Pesisir Selatan faktor pelanggaran yang dilakukan pengemudi yang kurang tertib berlalu lintas ini mencapai lebih dari $60 \%$ dari penyebab kecelakaan lalu lintas.

Penelitian ini menunjukkan berbagai alasan mengapa usia muda yaitu 16 sampai dengan 25 tahun berjumlah $48 \%$ dari keseluruhan pelaku kecelakaan lalulintas adalah tidak adanya kontrol emosi sehingga mereka cenderung melanggar rambu rambu lalulintas dan marka jalan. Alasan pemuda mengendarai kendaraan bermotor diantaranya tidak ada yang mengantar $(39,4 \%)$ 
serta sekolah yang jauh dari rumah $(11,7 \%)$. Kecelakaan sebagian besar terjadi adalah pada pengendara sepeda motor. Hal ini menggambarkan bahwa saat ini sepeda motor menjadi pilihan praktis dan menjadi kebutuhan.

Penggunaan sepeda motor di usia remaja menjadi hal penting, karena motor adalah kendaraan yang mampu mencapai tujuan dengan cepat dan merupakan bagian dari aktivitas kehidupan ke sekolah untuk para siswa. Pengemudi pemula memiliki peluang tiga kali lebih besar terlibat dalam kecelakaan dari pada pengemudi yang telah mahir. Lebih dari $50 \%$ kecelakaan pada tahun 2019 melibatkan anak muda dan pengemudi pemula berusia 16-25 tahun. Pengemudi pemula tidak di bekali dengan persiapan yang cukup mengenai keselamatan berlalu lintas seperti pengetahuan tentang rambu rambu lalulintas, perilaku berkendara yang aman, dan kemampuan/skill berkendara ditunjukkan dengan kepemilikan SIM.

Surat Izin Mengemudi (SIM) adalah bukti registrasi dan identifikasi yang diberikan oleh Polri kepada seseorang yang telah memenuhi persyaratan administrasi, sehat jasmani dan rohani, memahami peraturan lalu lintas dan terampil mengemudikan kendaraan bermotor. Namun hasil penelitian ini didapatkan bahwa responden yang memiliki SIM hanya 1,9\% saja. Hal ini karena untuk untuk mendapatkan SIM salah satu syaratnya adalah usia 17 tahun sementara umur responden belum memenuhi syarat untuk memilki SIM, dengan kata lain bahwa responden belum mempunyai keterampilan dalam mengemudikan kendaraan sepeda motor karena belum mempunyai SIM. Kondisi ini dapat meningkatkan risiko kecelakaan lalu lintas pada usia muda karena belum dimilikinya keterampilan/skill berkendara yang aman.

Berdasarkan hasil wawancara menyatakan bahwa prediksi jumlah korban kecelakaan Lalu Lintas di kabupaten Pesisir Selatan tidak hanya dipengaruhi jumlah penduduk dan jumlah kendaraan bermotor, tetapi juga jumlah kepemilikan SIM dan panjang serta kondisi jalan. Adanya pengendara tidak terampil berisiko lebih besar dalam menyebabkan kejadian kecelakaan Lalu Lintas dibanding pengendara terampil.

Kabupaten Pesisir Selatan mempunyai kondisi geografis sebagai dataran tinggi yang berbukit dan terletak di sepanjang pesisir pantai selatan Sumatera. Kondisi jalan raya dipesisir adalah sempit dan banyaknya tikungan tajam dengan pendakian dan turunan yang landai. Kondisi jalan ini berpotensi besar untuk terjadinya kecelakaan lalu lintas.

Disamping kondisi jalan faktor kondisi alam juga menjadi penyebab terjadinya kecelakaan lalulintas Kejadian yang seringkali terjadi saat hujan pengendara mengendarai kendaraannya dengan kecepatan tinggi dengan alasan agar cepat sampai tujuan, bisa jadi kecepatan tinggi inilah yang menjadi faktor pendukung terjadinya korban meninggal pada saat terjadi kecelakaan. Cuaca yang buruk seperti hujan mempengaruhi kelancaran berlalu lintas dan memicu terjadinya kecelakaan lalu lintas. Dalam kondisi hujan pandangan pengendara sangat terbatas, sehingga mudah sekali terjadi kesalahan yang tidak dapat diantisipasi. Selain itu hujan mengakibatkan jalan menjadi basah dan licin yang juga merupakan faktor penyebab kecelakaan lalu lintas. Hal-hal lain yang dapat memicu terjadinya kecelakaan saat cuaca hujan adalah jika pengendara tidak hati-hati. Hujan juga mempengaruhi kerja kendaraan seperti jarak pengereman menjadi lebih jauh, jalan menjadi lebih licin, dan jarak pandang menjadi lebih pendek karena 
lebatnya hujan. Jikalau terjadi hujan, pengendara cenderung akan menunda perjalanannya dan kejadian kecelakaan tinggi pada saat curah hujan rendah. Artinya, pengendara lebih berhati-hati ketika curah hujan tinggi, dan menganggap curah hujan rendah kurang beresiko. Dalam hal ini kaitannya dengan kondisi hujan dan jalan yang basah/licin, kembali pada faktor pengendara (manusia).

Kondisi alam lainnya di kabupaten Pesisir Selatan hewan ternak peliharaan masyarakat yaitu sapi yang dibiarkan berkeliaran tanpa tali. Sehingga hean sapi tersebut menjadi tidak terkendali dan berkeliaran seenaknya di jalan raya. Hewan tersebut berkeliaran pada terutama pada sore dan malam hari. Faktor ini menjadi salah satu penyebab terjadinya kecelakaan lalulintas. Namun angka yang ditunjukan berdasarkan statistik pelanggaran kecil dibandingkan dengan penyebab kecelakaan lalulintas lainnya.

Perangkat pengatur lalu lintas merupakan suatu instrumen yang diperlukan untuk mengatur kelancaran arus lalu lintas di jalan raya. Selain itu juga dapat berfungsi untuk menurunkan tingkat kecelakaan dan hambatan lalu lintas. Rambu lalu lintas adalah suatu tanda, simbol, isyarat atau semboyan yang bertujuan memberikan informasi atau petunjuk bagi pengguna jalan tentang kondisi jalan dan lingkungannya. Kesadaran pengemudi terhadap ramburambu Lalu Lintas di jalan raya perlu ada peningkatan. Terutama pada rambu lalu lintas menunjukkan lampu kuning. Pada penelitian ini kejadian kecelakaan di kota Painan sebagian terjadi pada mereka yang memiliki perilaku selalu melanggar lampu kuning. Sifat terburu buru pengemudi mengakibatkan potensi besar terjadinya kecelakaan.

Kesadaran pada kondisi Lalu Lintas dan rambu-rambu lalu lintas akan bisa menurunkan kejadian kecelakaan di jalan raya. Lampu lalu lintas merupakan alat pengatur lalu lintas yang dijalankan dengan listrik atau sejenisnya yang bertujuan untuk mengatur, mengarahkan serta memberikan peringatan kepada pengguna kendaraan. Pelanggaran terhadap lampu lalu lintas seperti melajukan kendaraan di saat lampu lalu lintas berwarna kuning menjadi salah satu penyebab terjadinya kecelekaan.

\section{Upaya Penanggulangan Kecelakaan Lalulintas Di Wilayah Hukum Polres Pesisir Selatan}

Aparat penegak hukum (polisi lalu lintas) berperan sebagai pencegah (politie toezicht) dan sebagai penindak (politie dwang) dalam fungsi politik. Di samping itu polisi lalu lintas juga melakukan fungsi regeling, misalnya, pengaturan tentang kewajiban bagi kendaraan bermotor tertentu untuk melengkapi dengan segitiga pengaman dan fungsi bestuur khususnya dalam hal perizinan atau begunstiging (misalnya, mengeluarkan Surat Izin Mengemudi). Tinjauan utama dari peraturan lalu lintas adalah untuk mempertinggi mutu kelancaran dan keamanan dari semua lalu lintas di jalan-jalan. Identifikasi masalah-masalah yang dihadapi di jalan raya berkisar pada lalu lintas.

Upaya penanggulangan kecelakaan lalulintas dan peningkatan keselamatan lalulintas dapat dilakukan melalui beberapa aspek antara lain aspek Rekayasa yaitu penyediaan dan pengembangan tempat istirahat, pemeliharaan jalan dan prasarananya, pemasangan rumble stripe, merapatkan jarak antra guide post, pemasangan marka, pemasangan warning light (lampu 
flip flop), pemasangan rambu, pembatasan kecepatan, memberikan fasilitas pejalan kaki, jalan yang lurus diberi belokan/dipersempit untuk mengurangi kecepatan, jalan tidak langsung mengakses ke jalan besar, yang semuanya itu intinya desain yang tepat pada setiap ruas jalan.

Aspek Hukum dapat dilakukan sosialisasi peraturan yang ada dan diberlakukan dengan arif-seksana, sehingga tidak terjadi pelanggaran lalulintas. Masyarakat taat pada hukum, bukan karena ada polisi tetapi kesadaran sendiri demi keselamatan. Banyaknya bentuk pelanggaran lalu lintas tersebut, maka diperlukan sosialisasi Undang - Undang No 22 tahun 2009 Tentang Lalu Lintas dan Angkutan Jalan terutama menginformasikan tentang pencegahan kecelakaan dan keselamatan lalulintas ditinjau dari sistem transportasi. Diharapkan dengan kegiatan sosialisasi ini, maka tingkat kesadaran berperilaku tertib dan disiplin berlalu lintas dapat meningkat, sehingga tercipta keselamatan, keamanan dan kenyamanan lalu lintas.

Pengguna jalan raya harus memahami hal hal yang harus diperhatikan untuk menghindari kecelakaan seperti Kondisi Kendaraan. Pemeliharaan kendaraan, dan usahakan tak hanya sekedar untuk memperpanjang usia mobil, tetapi berguna agar mobil dan motor tetapi agar kendaraan tetap terjaga. Dengan melakukan pemeliharaan, pemilik akan menyadari dan mendeteksi sejak dini apa saja masalah-masalah yang tengah dialami mobil dan motornya sebelum masalah itu menjadi besar mengakibatkan hal yang fatal.

Salah satu masalah pemeliharaan paling umum yang dapat menyebabkan kecelakaan adalah tekanan ban yang tidak tepat. Tekanan yang tidak merata pada ban bukan hanya dapat memengaruhi kinerja bahkan juga bisa menyebabkan ledakan, terutama saat mobil berada pada kecepatan tinggi. Wilayah penting lainnya ada pada rem mobil. Jika dilihat beberapa "kelembutan" di pedal rem, atau merasakan getaran ketika rem diterapkan, sebaiknya segera diperiksakan oleh seorang mekanik profesional.

Banyak pengemudi yang mengabaikan keselamatan lalu memacu kecepatan sangat tinggi. Meski dianggap mengejar waktu mereka namun hal itu selain membahayakan diri sendiri, juga membahayakan nyawa orang lain di sekitarnya. Selalu gunakan lampu sein di setiap kesempatan saat akan mengambil jalur lain atau berbelok. Selain itu, spion harus tak pernah luput dari pandangan pengemudi.

Penggunaan sabuk Pengaman yang kurang. Sabuk merupakan salah satu alat di dalam mobil yang dapat menyelamatkan nyawa. Sebagian besar pengendara menggunakan sabuk pengaman hanya karena takut pada polisi yang seharusnya pengendara lebih peduli pada keselamatan diri sendiri.

Agar terhindar dari halhal yang tak diinginkan, pengemudi sebaiknya selalu memperhatikan jarak aman saat berkendara. Pengemudi harus cukup cekatan untuk bereaksi jika mobil di depannya berhenti secara tiba-tiba. Secara non penal Upayaupaya yang telah dilakukan pihak Satlantas Polres Pesisir Selatan antara lain upaya Pre-emtif dan Preventif. Upaya preventif adalah tindak lanjut dari upaya pre-emtif.

Dalam upaya pre-emtif yang ditekankan adalah menghilangkan kesempatan untuk dilakukannya kejahatan. Dalam hal ini keberadaan Satlantas pada setiap pos keamanan yang berada di jalan-jalan sangatlah efektif dalam hal menutup kesempatan bagi para pengendara yang 
belum memiliki surat-surat untuk dapat membawa kendaraan bermotor di jalan dan juga mengawasi agar tidak dilakukannya pelanggaran yang mengakibatkan kecelakaan lalulintas.

\section{Kendala Dalam Upaya Penanggulangan Kecelakaan Lalulintas Di Wilayah Hukum Polres Pesisir Selatan}

Upaya penanggulangan kecelakaan lalulintas Polantas juga sering menemui berbagai kendala. Sesuai dengan misi Polantas adalah melindungi, mengayomi dan melayani masyarakat maka melalui kegiatan Pendidikan Masyarakat lalu lintas, penegakan hukum lalu lintas, pengkajian masalah lalu lintas, registrasi dan identifikasi kendaraan bermotor dan pengemudi di jalan.

Pada bagian pengkajian masalah lalu lintas merupakan salah satu upaya membangun kemitraan dan membangun kesadaran berlalu lintas para pengguna lalu lintas diantaranya dengan melakukan berbagai upaya pencegahan kecelakaan lalu lintas. Untuk itu berbagai upaya dalam menekan kecelakaan lalu lintas sangat dibutuhkan juga diperlukannya berbagai program yang dapat digunakan sebagai sarana koordinasi kepada instansi terkait lainnya sehingga dapat terciptanya kesadaran dan kedisiplinan berlalu lintas dalam rangka mewujudkan keamanan, keselamatan, ketertiban dan kelancaran lalu lintas di jalan umum.

Kemajuan sektor transportasi, dengan segala sarana dan prasarana teknologi pendukung yang ada, merupakan sarana sangat vital dalam kehidupan modern yang semakin berkembang saat ini, untuk memudahkan kita akses ke berbagai sumberdaya yang ada. Namun, pilihanpilihan atas moda transportasi ini haruslah memberikan jaminan bagi keselamatan hidup manusia, menempatkan keselamatan di atas segalanya. Pembangunan berdimensi manusia (human

development), disertai dengan teknologi transportasi berwajah manusiawi, haruslah menjadi kepedulian bersama. Karena faktor penyebab utama kecelakaan lalulintas adalah kesalahan manusia itu sendiri atau Human Error.

Adapun kendala yang ditemui dalam upaya penaggulangan kecelakaan lalulintas oleh satlantas Polres Pesisir Selatan adalah keterbatasan dana untuk pemberian pelayanan yang optimal kepada masyarakat merupakan sebuah hambatan dan masalah yang penting dalam pemberian pelayanan penanganan kecelakaan lalu lintas. Dalam penanganan kecelakaan, Polres Pesisir selatan mengalami keterbatasan dana, karena terbatasnya anggaran yang diberikan dari kantor. Dan keterbatasan dana ini cukup mengganggu dalam proses penanganan kecelakaan.

Kendala lain adalah keterbatasan sarana dan Prasarana. Keterbatasan sarana dan prasarana sangat mempengaruhi kinerja petugas dalam melakukan penanganan kecelakaan sebagai penyelenggaraan pelayanan kepada masyarakat. Kurangnya kesadaran masyarakat untuk melaporkan setiap kecelakaan yang dialami, menghambat kinerja kepolisian dalam melakukan pelayanan untuk menangani kecelakaan. Dengan tidak melaporkan kecelakaan yang terjadi, bukanlah hal yang baik pihak-pihak yang terlibat dalam kecelakaan tersebut, pasti akan berbuntut yang kurang mengenakkan. Polres pesisir selatan tidak dapat memberikan pelayanan penanganan kecelakaan lalu lintas, jika tidak ada masyarakatnya yang mau melaporkan. 
Secara eksternal kendala yang dihadapi dalam upaya penanggulangan kecelakaan lalulintas adalah Kurangnya kerjasama antara polisi lalu lintas dengan instansi lain yang berkaitan dengan lalu lintas seperti dengan dinas perhubungan dan pemerintahan nagari. Dalam usahanya untuk mengurangi kecelakaan lalu lintas yang melibatkan kendaraan akibat terjadinya tindak pidana lalu lintas atau tidak, yang bisa menimbulkan korban jiwa, seringkali menemui kesulitan dalam usahanya. Hal ini berkaitan dengan kurang kerja sama antara pihak kepolisian dengan instansi lain. Contohnya yaitu, tetap beroperasinya bus-bus yang tidak memenuhi standar kelayakan, dimana soal uji kelayakan tersebut merupakan kewenangan Dinas Perhubungan, dan pemeriksaan dokumen lulus uji kelayakan diterminal juga diperlukan kerja sama dengan dinas perhubungan sebagi pihak yang berwenang. Begitu juga dengan kendaraan bermotor yang begitu banyak dan mudah mendapatkannya.

Rendahnya Tingkat Kesadaran Hukum pengguna jalan dalam melakukan pekerjaannya yaitu mengendarai kendaraannya sesuai dengan standar operasional mengemudi yang baik dan benar sering tidak diterapkan dengan melanggar peraturan lalu lintas yang ada, contohnya dengan tidak menggunakan lampu sein apabila akan berbelok atau berpindah jalur, mengemudi secara ugal-ugalan, menaikan dan menurunkan penumpang di sembarang tempat, dan melanggar marka jalan maupun traffic light.

Pengendara mau mematuhi peraturan lalu lintas maupun rambu lalu lintas jika ada petugas kepolisian yang bertugas, apabila tidak ada petugas kepolisian yang bertugas mereka sering melanggar contohnya saja memaksa mendahului kendaraan dari sisi kiri bahu jalan oleh pengendara motor. Hal ini tentu sangat berbahaya dan rentan terjadi kecelakaan.

Di Pesisir Selatan banyak dilewati oleh pengendara bus dan truk roda 6 (enam) dan 8 (delapan) yang mengangkut minyak sawit. Tidak Patuhnya Perusahaan truk atau bus Terhadap Peraturan Yang Berlaku Peraturan Menteri Perhubungan nomor 35 tahun 2003 tentang Penyelenggaraan Angkutan Orang Di Jalan dengan Kendaraan Umum, tepatnya pada pasal 62 mengenai kewajiban pemegang izin trayek mewajibkan perusahaan salah satu contohnya yaitu, memperkerjakan pengemudi yang memenuhi persyaratan sesuai peraturan perundangan yang berlaku dan merupakan pengemudi perusahaan bersangkutan, namun sering ditemui dalam penyedikan kasus kecelakaan lalu lintas banyak pengemudi yang Surat Izin Mengemudi (SIM) telah habis masa berlakunya dan perusahaan tidak mengetahuinya, selain itu juga banyak ditemukan oleh pihak kepolisian bahwa pengemudi tidak memiliki Surat Izin Mengemudi (SIM) sesuai golongan kelas jalan, contohnya kendaraan bus harusnya memiliki SIM B2 umum tetapi juga ditemukan pengemudi hanya mempunyai SIM B1.

\section{KESIMPULAN}

Faktor kriminologi Tingginya Angka Kecelakaan Lalulintas Di Wilayah Hukum Polres Pesisir Selatan yang utama adalah faktor Kesalahan manusia atau Human error dan faktor Kondisi Jalan. Faktor kesalahan manusia antara lain tidak menaati peraturan yang ada, banyaknya pengemudi yang kurang tertib berlalu lintas. Tidak memiliki Surat Izin Mengemudi (SIM) Faktor kondisi jalan karena Kabupaten Pesisir Selatan mempunyai kondisi geografis 
sebagai dataran tinggi yang berbukit dan terletak di sepanjang pesisir pantai selatan Sumatera. Kondisi jalan raya dipesisir adalah sempit dan banyaknya tikungan tajam dengan pendakian dan turunan yang landai. Faktor lain hewan ternak peliharaan masyarakat yaitu sapi yang dibiarkan berkeliaran tanpa tali. Upaya Penanggulangan Kecelakaan Lalulintas Di Wilayah Hukum Polres Pesisir Selatan dilakukan dengan beberapa aspek yaitu aspek rekayasa pemeliharaan jalan dan prasarananya, pemasangan marka, pemasangan warning light (lampu flip flop), pemasangan rambu, pembatasan kecepatan.

\section{DAFTAR PUSTAKA}

Panadeng, Robert, Hernowo Wibowo, dan Bien Pasaribu, UndangUndang Lalu Lintas dan Angkutan Jalan, Pustaka Sinar Harapan, Jakarta, 1993

Soerjono Soekanto, Suatu Tinjauan Sosiologi Hukum Terhadap Masalah Masalah Sosial, Citra Aditya Bakti, Bandung, 1989 